\title{
HUBUNGAN PENGETAHUAN DAN IMPLEMENTASI PENCEGAHAN COVID-19 PADA PRAKTIK KEBIDANAN KOMUNITAS
}

\author{
Anita Dewi Lieskusumastuti ${ }^{1}$, Catur Setyorini ${ }^{2}$ \\ STIKES Mamba'ul 'Ulum Surakarta \\ ( anita.dewi712@yahoo.co.id )
}

\begin{abstract}
ABSTRAK
Latar Belakang: Pada situasi pandemi COVID-19 saat ini, berbagai pihak baik pemerintah maupun lembaga swasta telah melakukan upaya-upaya komunikasi secara serentak dan dalam waktu yang sama. Hal ini dapat memberikan keuntungan bagi masyarakat luas untuk secara cepat mendapatkan informasi terkini mengenai COVID-19. Namun disisi lain, pesan yang terlalu banyak dikeluarkan bersifat random dan selalu berubah sehingga pada akhirnya menghalangi orang untuk memahaminya dan mengubah perilakunya.

Tujuan: Penelitian ini bertujuan untuk mengetahui Hubungan Pengetahuan dan Implementasi Pencegahan COVID-19 pada Praktik Kebidanan Komunitas.

Metode: Desain penelitian survey analitik dengan pendekatan potong lintang. Populasinya adalah semua keluarga yang diberikan asuhan kebidanan komunitas oleh mahasiswa program studi Diploma III Kebidanan STIKES Mamba'ul 'Ulum Surakarta tahun 2019 sejumlah 80 responden. Teknik sampling adalah sampling kuota dengan jumlah responden 40 orang. Alat pengumpulan data kuesioner. Metode pengumpulan data menggunakan data primer. Analisa data univariat menggunakan distribusi frekuensi. Analisa bivariat menggunakan Kendall's Tau.

Hasil: Pengetahuan responden mayoritas baik sebanyak 44 responden (88\%). Implementasi pencegahan COVID-19 responden mayoritas tinggi sebanyak 31 responden (62\%). Hasil analisis uji korelasi Kendall's Tau 0,000<0,01, artinya bahwa ada hubungan signifikan antara Pengetahuan dengan Implementasi Pencegahan COVID-19.

Kesimpulan: Mayoritas pengetahuan baik, implementasi pencegahan COVID-19 tinggi dan ada hubungan signifikan antara Pengetahuan dengan Implementasi Pencegahan COVID-19
\end{abstract}

Kata kunci: Pengetahuan, Implementasi Pencegahan, COVID-19 


\title{
Knowledge And Implementation Of COVID-19 Prevention In Community Midwifery Practices
}

\begin{abstract}
Background: Background: In the current COVID-19 pandemic situation, various parties, both government and private institutions, have made communication efforts simultaneously and at the same time. This can provide an advantage for the wider community to quickly get the latest information about COVID-19. But on the other hand, messages that are issued too much are random and always changing so that in the end it prevents people from understanding it and changes their behavior.

Purpose: This study aims to determine the Relationship between Knowledge and Implementation of COVID-19 Prevention in Community Midwifery Practices.

Methods: Analytical survey research design with a cross sectional approach. The population is all families who are given community midwifery care by students of the Diploma III Midwifery study program STIKES Mamba'ul 'Ulum Surakarta in 2019 with a total of 80 respondents. The sampling technique was quota sampling with 40 respondents. Questionnaire data collection tool. The data collection method uses primary data. Univariate data analysis using frequency distribution. Bivariate analysis using Kendall's Tau.

Result: The majority of respondents' knowledge is good as many as 44 respondents (88\%). The majority of respondents implementing COVID-19 prevention were high as many as 31 respondents (62\%). The results of the analysis of Kendall's Tau correlation test 0,000<0.01, meaning that there is a significant relationship between Knowledge and the implementation of COVID-19 prevention.
\end{abstract}

Conclusion: The majority of knowledge is good, the implementation of COVID-19 prevention is high and there is a significant relationship between Knowledge and Implementation of COVID-19 prevention

Keywords: Knowledge, Implementation of Prevention, COVID-19 


\section{PENDAHULUAN}

Coronavirus disease 2019 (COVID-19) merupakan penyakit jenis baru yang disebabkan oleh virus Severe Acute Respiratory Syndrome Coronavirus-2 (SARS-Cov-2) yang sebelumnya disebut Novel Coronavirus (2019-nCov). Virus baru ini sangat menular dan cepat menyebar secara global (Rahayu dkk, 2020). Virus SARS-Cov-2 merupakan Coronavirus, jenis baru yang menyebabkan epidemic, dilaporkan pertama kali di Wuhan Tiongkok pada tanggal 31 Desember 2012 (Burhan dkk, 2020). World Health Organization (WHO) telah menyatakan COVID-19 sebagai global pandemi dan di Indonesia dinyatakan sebagai jenis penyakit yang menimbulkan Kedaruratan Kesehatan Masyarakat (KKM) serta bencana non alam (Sab'atmaja, dkk, 2020).

Infeksi coronavirus ditandai dengan demam dan gejala pernapasan seperti batuk sesak napas dan kesulitan bernapas. Pada kondisi parah dapat menyebabkan pneumonia, sindrom pernapasan akit, gagal ginjal, bahkan kematian (Rahayu dkk, 2020). Gejala klinis ringan lainnya seperti faringitis sampai berat seperti SARS atau MERS (Middle East respiratory syndrome) serta beberapa strain menyebabkan diare pada dewasa (Burhan dkk, 2020). Sebanyak $80 \%$ kasus COVID-19 bersifat ringan seperti pilek, sakit tenggorokan batuk dan demam, sehingga perawatan yang cukup dapat memulihkan dalam waktu cepat. Sekitar 1 dari setiap 6 orang akan menderita sakit yang parah, seperti pneumonia yang muncul bertahap. Angka kematian penyakit ini rendah (sekitar 3\%), namun bagi lansia dan orang komorbid (seperti diabetes, tekanan darah tinggi, penyakit paru kronis missal TBC dan asma, dan penyakit jantung) maka lebih rentan untuk menjadi sakit parah (Ginting, dkk, 2020). Surveilans per tanggal 12 November 2020, Pemerintah mengumumkan 452.291 kasus konfirmasi COVID-19 (4.173 kasus baru), 14.933 kasus kematian (97 kasus baru), dan 382.084 kasus sembuh dari 503 kabupaten/kota di 34 provinsi (WHO, 2020).

Penularan virus corona dapat terjadi melalui percikan (droplet) yang tersebar ketika seseorang batuk/bersin dan atau berbicara. Droplet bisa jatuh ke permukaan benda lalu pindah ke tangan dan akhirnya masuk ke dalam tubuh orang lain lewat mata, hidung dan mulut. Karena itu perilaku pakai masker, cuci tangan pakai sabun (CTPS) dan jaga jarak merupakan 3 perilaku kunci yang akan menghindari kita dari perpindahan virus. Masker menutupi hidung dan mulut, CTPS membersihkan tangan dari virus dan jaga jarak menjauhkan dari menghirup droplet yang dicipratkan melalui mulut atau hidung penderita (Ginting, dkk, 2020). Cara penyebaran beberapa virus atau patogen dapat melalui kontak dekat, lingkungan atau benda yang terkontaminasi virus, droplet saluran napas dan partikel airborne (Burhan dkk, 2020).

SARS-Cov-2 dapat mengenai pada semua individu dari segala usia meskipun yang paling sering terkena orang dewasa usia pertengahan dan lebih tua (Rahayu, 2020). Semua orang secara umum rentan terinfeksi. Jika terpapar virus dalam jumlah besar dalam satu waktu, dapat menimbulkan penyakit walaupun sistem imun tubuh berfungsi normal. Orang-orang dengan sistem imun lemah seperti orangtua, wanita hamil, dan kondisi lainnya, penyakit dapat secara progresif lebih cepat dan parah. Infeksi Coronavirus menimbulkan sistem 
kekebalan tubuh yang lemah terhadap virus ini lagi sehingga dapat terjadi reinfeksi (Burhan dkk, 2020).

Penelitian dengan data terbatas menunjukkan belum ada bukti bahwa ibu hamil berisiko lebih tinggi mengalami sakit parah akibat COVID-19 daripada populasi umum. Namun, karena perubahan dalam tubuh dan sistem kekebalan tubuh, bahwa wanita hamil dapat sangat terpengaruh oleh beberapa infeksi pernapasan. Penting bagi wanita hamil mengambil tindakan pencegahan melindungi diri terhadap Virus Corona dan melaporkan gejala ke penyedia layanan kesehatan. Semua wanita hamil, termasuk mereka yang terinfeksi atau dicurigai terinfeksi virus corona, mempunyai hal perawatan berkualitas tinggi sebelum, selama dan setelah melahirkan (Kemenkes RI, 2020). Bidan sesuai dengan standar kompetensi, standar profesi dan izin praktik memiliki kemampuan dan kewenangan untuk memberikan pelayanan kesehatan kepada ibu dan anak sesuai tahapan siklus kehidupannya. Upaya meningkatkan kelangsungan dan kualitas ibu dan anak dilakukan dengan menekankan upaya promotif dan preventif yang sama pentingnya dengan upaya kuratif dan rehabilitatif pada tiap siklus kehidupan (Pusdiklatnakes RI, 2014).

Upaya yang mengedepankan pendekatan promotif dan preventif dengan menggalang keterlibatan semua komponen masyarakat melalui jalinan kemitraan sangat diperlukan, karena jumlah pasien COVID-19 yang semakin meningkat. Himbauan tentang pentingnya pembatasan fisik dan sosial, menghindari kerumunan, tinggal di rumah, belajar, bekerja dan beribadah di rumah telah diatur dalam kebijakan pemerintah. Pemerintah telah melakukan antisipasi untuk menanggulangi pandemi COVID-19 dengan mengeluarkan Peraturan Pemerintah RI nomor 21 tahun 2020 tentang Pembatasan Sosial Berskala Besar dalam rangka Percepatan Penanganan COVID-19. Kebijakan pemerintah ini merupakan regulasi yang mengatur "social and physical distancing" yang harus dilakukan di tingkat masyarakat (Sab'atmaja, dkk, 2020).

Peran bidan sebagai penggerak masyarakat memiliki kemampuan memfasilitasi keluarga dan masyarakat agar memahami, mendukung dan melaksanakan pesan-pesan kesehatan khususnya tentang COVID-19 bekerjasama dengan berbagai lintas sektoral dengan menggunakan prinsip partnership dan pemberdayaan masyarakat sesuai kewenanangan dan lingkup praktik bidan. Pelayanan kesehatan sesuai standar tidak hanya ditekankan pada tingkat pelayanan (in-service) namun juga pada tingkat pendidikan (pre-service) khususnya institusi pendidikan kebidanan berkewajiban menghasilkan bidan yang kompeten dan dapat memberikan pelayanan sesuai standar pelayanan kebidanan. Pada kegiatan praktik kebidanan komunitas mahasiswa bidan berperan dalam berkomunikasi secara efektif dengan perempuan, keluarga dan masyarakat, terutama pada kondisi pandemi COVID-19 saat ini untuk memastikan pemahaman masyarakat akan pengetahuan dan implementasi pencegahan virus COVID-19 untuk meningkatkan kelangsungan dan kualitas hidup (Pusdiklatnakes RI, 2014). Hal ini didukung penelitian oleh Moudy dan Syakurah (2020) yang menunjukkan terdapat hubungan yang signifikan antara pengetahuan individu dengan tindakan individu mengenai COVID-19 $(\mathrm{p}=0,0000<0,05)$. 
Pada situasi pandemi COVID-19 saat ini, berbagai pihak baik pemerintah maupun lembaga swasta telah melakukan upaya-upaya komunikasi secara serentak dan dalam waktu yang sama. Hal ini dapat memberikan keuntungan bagi masyarakat luas untuk secara cepat mendapatkan informasi terkini mengenai COVID-19. Namun disisi lain, pesan yang terlalu banyak dikeluarkan bersifat random dan selalu berubah sehingga pada akhirnya menghalangi orang untuk memahaminya dan mengubah perilakunya (Ginting dkk, 2020).

Badan Litbangkes (2020) telah melakukan studi dengan hasil bahwa sebagian besar masyarakat dengan berbagai argumentasi menyatakan sulit untuk melakukan physical distancing atau social distancing dan masih ada sebagian saling kontak dengan orang lain. Selain itu, ditemukan pula masih ada sebagian warga masyarakat yang keluar rumah dengan tidak menggunakan masker dan sarung tangan. Selanjutnya masih ada juga masyarakat sewaktu pulang ke rumah tidak melakukan cuci tangan dengan sabun atau mandi (Sab'atmaja, dkk, 2020).

Berdasarkan uraian diatas, penulis tertarik melakukan penelitian tentang Hubungan Pengetahuan dan Implementasi Pencegahan COVID-19 pada Praktik Kebidanan Komunitas. Selain itu fakta yang ada menunjukkan tingkat pemahaman dan kesadaran masyarakat terhadap tindakan pencegahan penularan COVID-19 cukup tinggi, namun tidak dibarengi dengan praktek disiplin dalam implementasi (Sab'atmaja, dkk, 2020).

\section{METODE PENELITIAN}

Desain penelitian ini menggunakan rancangan survey analitik dengan pendekatan potong lintang. Populasi dalam penelitian ini adalah semua keluarga yang diberikan asuhan kebidanan komunitas oleh mahasiswa program studi Diploma III Kebidanan STIKES Mamba'ul 'Ulum Surakarta tahun 2019 sejumlah 80 responden. Teknik pengambilan sampel adalah sampling kuota. Sampel pada penelitian ini adalah keluarga yang diberikan asuhan kebidanan komunitas oleh mahasiswa program studi Diploma III Kebidanan STIKES Mamba'ul 'Ulum Surakarta tahun 2019 sejumlah 50 responden

Metode pengumpulan data menggunakan data primer. Alat pengumpulan data menggunakan kuesioner Pengetahuan dan kuesioner implementasi pencegahan covid 19. Uji validitas menggunakan product moment, dikatakan valid apabila $r$ hitung lebih besar dari $r$ tabel $(0,361 ; n=30)$. Sedangkan untuk mengukur reliabilitas instrument penelitian ini menggunakan Alpha Cronbach, instrumen dinyatakan reliable apabila nilai Alpha Cronbach $>0,60$. Perhitungan validitas dan reliabilitas alat ukur dalam penelitian ini menggunakan alat bantu komputer program IBM SPSS versi 26.

Data yang telah terkumpul akan diolah dan dilakukan uji analisis. Uji statistik analisis univariat menggunakan distribusi frekuensi dan analisis bivariat menggunakan uji statistik Kendall Tau, dengan derajat kepercayaan 99\%. Analisa data menggunakan alat bantu komputer program IBM SPSS versi 26. 


\section{HASIL DAN PEMBAHASAN}

\section{Hasil}

Tabel 1 Distribusi Frekuensi Pengetahuan COVID-19

\begin{tabular}{|c|c|c|c|c|}
\hline Pengetahuan COVID-19 & \multicolumn{2}{|c|}{ Frekwensi } & \multicolumn{2}{|c|}{$\begin{array}{l}\text { Prosentase } \\
(\%)\end{array}$} \\
\hline \multicolumn{5}{|l|}{ Kategori } \\
\hline Baik & \multicolumn{2}{|c|}{44} & \multicolumn{2}{|c|}{88} \\
\hline Cukup & \multicolumn{2}{|c|}{6} & \multicolumn{2}{|c|}{12} \\
\hline Total & & & & \\
\hline \multirow[t]{2}{*}{ Indikator Pernyataan } & \multicolumn{2}{|c|}{$\begin{array}{l}\text { Jawaban } \\
\text { Benar }\end{array}$} & \multicolumn{2}{|c|}{$\begin{array}{l}\text { Jawaban } \\
\text { Salah }\end{array}$} \\
\hline & $\mathbf{f}$ & $\%$ & $\mathbf{f}$ & $\%$ \\
\hline pengertian Covid-19; & 45 & 90 & 5 & 10 \\
\hline Pengertian Pandemi Covid-19; & 44 & 88 & 6 & 12 \\
\hline Gejala klinis penyakit Covid-19; & 49 & 98 & 1 & 2 \\
\hline Cara penularan Covid-19 melalui droplets; & 42 & 84 & 8 & 16 \\
\hline Cara penularan Covid-19 melalui kontak pribadi; & 49 & 9 & 1 & 2 \\
\hline $\begin{array}{l}\text { Cara penularan Covid-19 melalui menyentuh } \\
\text { benda/permukaan, mulut, hidung, mata; }\end{array}$ & 45 & 90 & 5 & 10 \\
\hline Masa inkubasi Covid-19; & 40 & 80 & 10 & 20 \\
\hline Kelompok risiko tinggi Penyakit Covid-19; & 42 & 84 & 8 & 16 \\
\hline \multicolumn{5}{|l|}{ Pengetahuan tentang pencegahan virus Covid-19: } \\
\hline Memakai masker; & 50 & 100 & 0 & 0 \\
\hline Mencuci tangan; & 49 & 98 & 1 & 2 \\
\hline Menggunakan handsanitizer; & 48 & 96 & 2 & 4 \\
\hline Physical distancing; & 47 & 94 & 3 & 6 \\
\hline Sosial distancing; & 49 & 98 & 1 & 2 \\
\hline $\begin{array}{l}\text { Tidak menyentuh mata, hidung, mulut sebelum mencuci } \\
\text { tangan; }\end{array}$ & 45 & 90 & 5 & 10 \\
\hline Tidak keluar rumah jika merasa tidak enak badan; & 50 & 100 & 0 & 0 \\
\hline $\begin{array}{l}\text { Jika demam, batuk atau kesulitan bernafas segera mencari } \\
\text { bantuan medis; }\end{array}$ & 45 & 90 & 5 & 10 \\
\hline Etika batuk dan bersin; & 47 & 94 & 3 & 6 \\
\hline $\begin{array}{l}\text { Segera mengganti baju/mandi sesampainya dirumah } \\
\text { setelah berpergian; }\end{array}$ & 43 & 86 & 7 & 14 \\
\hline Desinfektan permukaan benda dirumah; & 47 & 94 & 3 & 6 \\
\hline Meningkatkan imunitas : Gizi seimbang; & 49 & 98 & 1 & 2 \\
\hline Meningkatkan imunitas : Tidak merokok; & 43 & 86 & 7 & 14 \\
\hline Meningkatkan imunitas : Suplemen vitamin; & 42 & 84 & 8 & 16 \\
\hline Meningkatkan imunitas : Aktifitas fisik; & 48 & 96 & 2 & 4 \\
\hline Meningkatkan imunitas : Istirahat cukup; & 49 & 98 & 1 & 2 \\
\hline $\begin{array}{l}\text { Meningkatkan imunitas : mengendalikan penyakit } \\
\text { penyerta; }\end{array}$ & 48 & 96 & 2 & 4 \\
\hline Hindari stress & 48 & 96 & 2 & 4 \\
\hline
\end{tabular}

Tabel 1 menunjukkan sebagian besar responden memiliki pengetahuan baik sebanyak 44 responden $(88 \%)$. Dilihat dari item pernyataan kuesioner pengetahuan menunjukkan bahwa responden menjawab benar sebesar $100 \%$ mengenai pencegahan virus COVID-19 dengan memakai masker dan tidak keluar rumah jika merasa tidak enak badan. 
Anita Dewi Lieskusumastuti, Catur Setyorini (Hubungan Pengetahuan Dan Implementasi Pencegahan Covid-19 Pada Praktik Kebidanan Komunitas)

Tabel 2 Distribusi Frekuensi Implementasi Pencegahan COVID-19

\begin{tabular}{|c|c|c|c|c|}
\hline Implementasi Pencegahan COVID-19 & \multicolumn{2}{|c|}{ Frekwensi } & \multicolumn{2}{|c|}{$\begin{array}{c}\text { Prosentase } \\
(\%)\end{array}$} \\
\hline \multicolumn{5}{|l|}{ Kategori } \\
\hline Tinggi & & & & \\
\hline Sedang & & & & \\
\hline Rendah & & & & \\
\hline Total & & & & \\
\hline \multirow[t]{2}{*}{ Indikator Pernyataan } & \multicolumn{2}{|c|}{$\begin{array}{l}\text { Jawaban } \\
\text { Benar }\end{array}$} & \multicolumn{2}{|c|}{$\begin{array}{l}\text { Jawaban } \\
\text { Salah }\end{array}$} \\
\hline & $\mathbf{f}$ & $\%$ & $\mathbf{f}$ & $\%$ \\
\hline Memakai masker; & 50 & 100 & 0 & 0 \\
\hline Mencuci tangan; & 50 & 100 & 0 & 0 \\
\hline Menggunakan handsanitizer; & 43 & 86 & 7 & 14 \\
\hline Physical distancing; & 45 & 90 & 5 & 10 \\
\hline Sosial distancing; & 48 & 96 & 2 & 4 \\
\hline $\begin{array}{l}\text { Tidak menyentuh mata, hidung, mulut sebelum } \\
\text { mencuci tangan; }\end{array}$ & 45 & 90 & 5 & 10 \\
\hline Tidak keluar rumah jika merasa tidak enak badan; & 44 & 88 & 6 & 12 \\
\hline $\begin{array}{l}\text { Jika demam, batuk atau kesulitan bernafas segera } \\
\text { mencari bantuan medis; }\end{array}$ & 50 & 100 & 0 & 0 \\
\hline Etika batuk dan bersin; & 46 & 86 & 4 & 8 \\
\hline $\begin{array}{l}\text { Segera mengganti baju/mandi sesampainya dirumah } \\
\text { setelah berpergian; }\end{array}$ & 47 & 94 & 3 & 6 \\
\hline Desinfektan permukaan benda dirumah; & 43 & 86 & 7 & 14 \\
\hline Meningkatkan imunitas : Gizi seimbang; & 49 & 98 & 1 & 2 \\
\hline Meningkatkan imunitas : Tidak merokok; & 42 & 84 & 8 & 16 \\
\hline Meningkatkan imunitas : Suplemen vitamin; & 44 & 88 & 6 & 12 \\
\hline Meningkatkan imunitas : Aktifitas fisik; & 48 & 96 & 2 & 4 \\
\hline Meningkatkan imunitas : Istirahat cukup; & 49 & 98 & 1 & 2 \\
\hline $\begin{array}{l}\text { Meningkatkan imunitas : mengendalikan penyakit } \\
\text { penyerta; }\end{array}$ & 47 & 94 & 3 & 6 \\
\hline Hindari stress & 49 & 98 & 1 & 2 \\
\hline
\end{tabular}

Tabel 2 menunjukkan sebagian besar responden Implementasi Pencegahan COVID-19 termasuk kategori tinggi sebanyak 31 responden (62\%). Dilihat dari item pernyataan kuesioner Implementasi Pencegahan COVID-19 menunjukkan bahwa responden menjawab benar sebesar $100 \%$ mengenai memakai masker, mencuci tangan dan jika demam, batuk atau kesulitan bernafas segera mencari bantuan medis.

Tabel 3 Tabulasi Silang Hubungan Pengetahuan dan Implementasi Pencegahan COVID-19

\begin{tabular}{lccccccc}
\hline \multirow{2}{*}{\begin{tabular}{c} 
Pengetahuan \\
\multicolumn{1}{c}{ (X) }
\end{tabular}} & \multicolumn{9}{c}{ Rendah } & \multicolumn{2}{c}{ Sedang } & \multicolumn{2}{c}{ Tinggi } & \multirow{2}{*}{ Total } \\
& $\mathrm{f}$ & $\%$ & $\mathrm{f}$ & $\%$ & $\mathrm{f}$ & $\%$ & $\mathrm{f}(\%)$ \\
\hline Cukup & 5 & 83,3 & 1 & 16,7 & 0 & 0,0 & $6(100)$ \\
Baik & 0 & 0,0 & 13 & 29,5 & 31 & 70,5 & $44(100)$ \\
$\quad$ Total & 5 & 10,0 & 14 & 28,0 & 31 & 62,0 & $50(100)$ \\
\hline
\end{tabular}


Tabel 3 menunjukkan sebagian besar responden memiliki pengetahuan baik dengan implementasi pencegahan COVID-19 termasuk kategori tinggi sebesar 31 responden $(70,5 \%)$.

Tabel 4 Analisis Kendall's Tau Hubungan Pengetahuan dan Implementasi Pencegahan COVID-19

\begin{tabular}{clcr}
\hline & & $\begin{array}{c}\text { Pengetahuan } \\
\text { (X) }\end{array}$ & \multicolumn{2}{c}{ Implementasi } \\
Pencegahan (Y)
\end{tabular}

Tabel 4 menunjukkan bahwa hasil analisis uji korelasi Kendall's Tau pada nilai signifikansi atau Sig. (2-tailed) antara variabel Pengetahuan dengan Implementasi Pencegahan COVID-19 pada taraf signifikasi $1 \%$ adalah $0,000<0,01$, maka dapat disimpulkan bahwa ada hubungan yang signifikan antara variabel Pengetahuan dengan Implementasi Pencegahan COVID-19. Diketahui dari nilai koefisien korelasi (Correlation Coefficient) antara variabel Pengetahuan dengan Implementasi Pencegahan COVID-19 adalah sebesar 0,602. Maka dapat disimpulkan bahwa ada hubungan antara variabel Pengetahuan dengan Implementasi Pencegahan COVID-19 adalah kuat. Arah hubungan variabel bernilai positif bahwa jika Pengetahuan semakin baik maka implementasi pencegahan COVID-19 akan semakin tinggi.

\section{Pembahasan}

Berdasarkan tabel 1 diketahui bahwa sebagian besar responden termasuk dalam kategori pengetahuan baik. Hasil ini didukung oleh penelitian Yanti dkk (2020) bahwa mayoritas masyarakat memiliki tingkat pengetahuan tentang pandemi COVID-19 yang baik (70\%). Hal ini berarti masyarakat sudah mengetahui bahwa COVID-19 adalah nama penyakit yang disebabkan jenis virus corona yang paling baru, dan telah menyebar secara luas di dunia. Istilah pandemi COVID-19 terkesan menakutkan, akan tetapi sebenarnya tidak ada kaitannya dengan keganasan penyakit melainkan lebih kepada luasnya penyebarannya (Ginting, dkk, 2020). Hasil penelitian lain yang sejalan menunjukkan responden terbanyak memiliki pengetahuan penyakit COVID-19 baik sebanyak 43 responden (69,35\%) (Sari, 2020). Penelitian Putra,dkk (2020) juga menunjukkan bahwa sebagian besar responden memiliki pengetahuan baik sebanyak 59 orang $(51,8 \%)$

Diketahui dari item pernyataan kuesioner pengetahuan menunjukkan bahwa responden menjawab benar sebesar $100 \%$ mengenai pencegahan virus COVID-19 dengan memakai masker dan tidak keluar rumah jika merasa tidak enak badan. Masker dapat melindungi diri sendiri dan orang lain. Masker dapat 
melindungi diri sendiri karena mencegah masuknya droplet yang keluar saat kita batuk/bersin/berbicara sehingga kita tidak tertular. Masker dapat melindungi orang lain karena menahan droplet yang keluar saat kita batuk/bersin/berbicara sehingga tidak menularkan virus kepada orang lain (BNPB, 2019).

Pencegahan penularan COVID-19 salah satunya dengan tidak keluar rumah jika merasa tidak enak badan. Gejala COVID-19 yang dialami biasanya bersifat ringan dan muncul secara bertahap. Sekitar 1 dari setiap 6 orang akan menderita sakit yang parah, seperti pneumonia atau kesulitan bernafas, yang muncul bertahap (Ginting, dkk, 2020).

Berdasarkan tabel 1 mayoritas responden memiliki pengetahuan yang baik mengenai COVID-19, namun dilihat dari jawaban salah, mayoritas jawaban salah pada responden yakni pengetahuan tentang masa inkubasi sebesar 10 orang (20\%). Masa inkubasi (dari masuknya virus ke dalam tubuh sampai munculnya gejala awal) penyakit infeksi virus Corona adalah 1-14 hari, dengan rata-rata timbulnya gejala selama 5 hari (Kemenkes, 2020).

Mayoritas jawaban salah pada responden pada penelitian ini yakni pengetahuan tentang cara penularan melalui droplets sebanyak 8 orang (16\%). Penyakit virus corona dapat menyebar melalui percikan air (droplets) dair hidung atau mulut pada saat berbicara, batuk atau bersin. Droplet tersebut kemudian jatuh pada benda di sekitarnya. Kemudian jika ada orang lain menyentuh benda yang sudah terkontaminasi dengan droplet tersebut, lalu orang itu menyentuh mata, hidung atau mulut maka orang itu dapat terinfeksi virus corona (Kemenkes, 2020).

Pada hasil penelitian ini diketahui mayoritas jawaban salah pada responden yakni pengetahuan tentang kelompok risiko tinggi penyakit COVID-19 sebanyak 8 orang (16\%). Tidak ada batasan usia orang-orang dapat terinfeksi oleh virus corona. Namun orang yang lebih tua dan orang dengan kondisi medis yang sudah ada sebelumnya (seperti asma, diabetes, penyakit jantung) tampaknya lebih rentang untuk menderita sakit parah (Kemenkes, 2020).

Mayoritas jawaban salah responden pada pernyataan pengetahuan yaitu tentang meningkatkan imunitas dengan suplemen vitamin sebanyak 8 orang 916\%). Suplemen berupa vitamin ditujukan untuk mengatasi kekurangan mikronutrien dalam asupan makanan. Kekebalan terhadap penularan berbagai penyakit infeksi diperoleh dari nutrisi lengkap seimbang, istirahat yang cukup, aktifitas fisik sesuai usia, penerapan perilaku hidup bersih sehat, serta usaha pencegahan penularan infeksi (Kemenkes, 2020).

Berdasarkan Tabel 2, menunjukkan sebagian besar responden Implementasi Pencegahan COVID-19 termasuk kategori tinggi sebanyak 31 responden $(62 \%)$. Diketahui dari item pernyataan kuesioner Implementasi Pencegahan COVID-19 menunjukkan bahwa responden menjawab benar sebesar $100 \%$ mengenai memakai masker, mencuci tangan dan jika demam, batuk atau kesulitan bernafas segera mencari bantuan medis. Hasil ini didukung oleh penelitian Yanti dkk (2020) bahwa mayoritas peserta menjawab "Selalu" pada setiap poin pernyataan perilaku masyarakat di masa pandemi COVID-19 yang positif dan sebagian besar menjawab "Tidak Pernah" pada poin pernyataan perilaku masyarakat di masa pandemi COVID-19 yang negatif. 
COVID-19 merupakan infeksi virus yang sangat meresahkan, karena sangat mudah menular dan berakibat fatal, bila tidak mendapatkan penanganan yang adekuat. Pencegahan penularan COVID-19, dengan melakukan perilaku hidup bersih dan sehat (PHBS) secara konsisten. Dari data yang ada sekitar 80\%, penderita dapat sembuh tanpa perawatan khusus, melainkan dengan menerapkan PHBS pencegahan COVID-19 (Pasaribu, dkk, 2020). Penerapan PHBS meliputi cuci tangan memakai sabun dengan air mengalir, konsumsi gizi seimbang, istirahat cukup, tidak merokok, aktifitas fisik di rumah, kendalikan penyakit penyerta (Kemenkes RI, 2020). - pedoman pemberdayaan masy dalam pencegahan covid 19 di rt rw desa

Strategi pemberdayaan masyarakat salah satunya dengan peningkatan pengetahuan dan kemampuan masyarakat dalam mengenali dan mengatasi permasalahan kesehatan yang dihadapi dan peningkatan kesadaran masyarakat melalui penggerakan masyarakat (Permenkes RI Nomor 8, 2019). Implementasi kegiatan pemberdayaan masyarakat meliputi kesehatan ibu, bayi, dan balita; anak usia sekolah dan remaja; usia produktif; lanjut usia dan sebagainya dapat dilakukan melalui praktik kebidanan komunitas dengan upaya promotif dan preventif sebagai pencegahan COVID-19 berpedoman pada protokol kesehatan dengan baik.

Penggunaan masker dapat menurunkan risiko tertular hingga $45 \%$ dibandingkan tidak sama sekali. Riset dari Badan Pusat Statistik (Hasil Survey Sosial Demografi Dampak COVID-19 tahun 2020) menunjukkan bahwa ada sekitar $80 \%$ penduduk yang mengaku sudah menggunakan masker namun pada praktiknya masih banyak yang salah dalam menggunakannya sehingga tidak efektif dalam mencegah risiko penularan (Kemenkes RI, 2020). Hasil penelitian ini juga sejalan dengan penelitian Sari (2020) bahwa sebagian besar masyarakat patuh menggunakan masker sebanyak 46 responden $(74,19 \%)$.

Virus mati dengan sabun dan air mengalir. Melakukan enam langkah cuci tangan memakai sabun dan air mengalir selama minimal 20 detik, atau mencuci tangan dengan handsanitizer berbasis alkohol minimal 60\%. Mencuci tangan sesering mungkin, terutama sebelum menyentuh mata, hidung dan mulut (BNPB, 2020). Perlu diwaspadai bahwa terdapat orang yang sudah terinfeksi tetapi tidak menunjukkan gejala apapun dan tetap merasa sehat. Jika mengalami gejalagejalanya, segera berkonsultasi ke fasilitas kesehatan (Ginting, dkk, 2020).

Berdasarkan Tabel 3, diketahui bahwa sebagian besar responden memiliki pengetahuan baik dengan implementasi pencegahan COVID-19 termasuk kategori tinggi sebesar 31 responden $(70,5 \%)$. Penelitian ini sejalan dengan penelitian Gannika (2020) didapatkan bahwa responden yang tingkat pendidikannya tinggi dengan perilaku pencegahan COVID-19 baik sebanyak 127 (85,2\%). Hal ini menunjukkan bahwa masyarakat mempunyai tingkat pengetahuan terhadap COVID-19 yang baik serta tingkat kepercayaan, sikap dan kepedulian mengenai penyebab, gejala dan transmisi serta aspek sosial budaya yang mempengaruhi perilaku dalam pencegahan virus corona meskipun banyak berita tidak benar seputar COVID-19 pada era digital media dan banyaknya sumber media. Persepsi risiko dan ketakutan terhadap COVID-19 dapat menyebabkan kesalahpahaman masyarakat dalam menerima banyaknya informasi yang belum diketahui 
kebenarannya (Kemenkes RI, 2020). Hasil penelitian ini sejalan dengan penelitian Sari (2020) bahwa responden sebagian besar menyatakan pengetahuan baik memiliki kepatuhan menggunakan masker sebanyak 36 responden serta dari uji analisis bivariat dengan Chi Square nilai p 0,004 $(<0,05)$ artinya ada hubungan antara pengetahuan masyarakat dengan kepatuhan menggunakan masker. Hasil penelitian ini juga didukung oleh Wiranti (2020) bahwa mayoritas responden kategori pengetahuan baik memiliki kepatuhan tinggi terhadap kebijakan PSBB sebesar 89 responden (57,1\%). Penelitian Putra dkk (2020) menunjukkan bahwa berdasarkan perilaku yang mengukur tingkat kerentanan responden terhadap infeksi corona virus yakni sebagian besar responden memiliki perilaku yang baik sebanyak 76 orang $(66,7 \%)$ dan aktualisasi atau sikap dalam hal tindakan preventif sehari-hari yang dilakukan oleh partisipan untuk pencegahan COVID-19 adalah sebagian besar aktualisasi praktik baik sebanyak 64 orang $(56,1 \%)$.

Berdasarkan Tabel 4, menunjukkan bahwa ada hubungan yang signifikans antara pengetahuan dan implementasi pencegahan COVID-19. Hasil analisis uji korelasi Kendall's Tau pada nilai signifikansi atau Sig. (2-tailed) antara variabel Pengetahuan dengan Implementasi Pencegahan COVID-19 pada taraf signifikasi $1 \%$ adalah $0,000<0,01$, maka dapat disimpulkan bahwa ada hubungan yang signifikan antara variabel Pengetahuan dengan Implementasi Pencegahan COVID-19. Diketahui dari nilai koefisien korelasi (Correlation Coefficient) antara variabel Pengetahuan dengan Implementasi Pencegahan COVID-19 adalah sebesar 0,602. Maka dapat disimpulkan bahwa ada hubungan antara variabel Pengetahuan dengan Implementasi Pencegahan COVID-19 adalah kuat. Serta arah hubungan variabel bernilai positif bahwa jika Pengetahuan semakin baik maka implementasi pencegahan COVID-19 akan semakin tinggi. Hasil penelitian ini sejalan dengan penelitian Sari (2020) dari uji analisis bivariat dengan Chi Square nilai p $0,004(<0,05)$ artinya ada hubungan antara pengetahuan masyarakat dengan kepatuhan menggunakan masker. Beberapa hasil penelitian secara signifikan menunjukkan korelasi positif antara pengetahuan yang dimiliki masyarakat dengan tindakan positif masyarakat dalam upaya pencegahan penularan COVID-19 (Ganing, 2020).

Hasil penelitian ini juga didukung oleh Wiranti (2020) menunjukkan adanya hubungan antara pengetahuan responden terhadap kebijakan PSBB dengan kepatuhan terhadap kebijakan PSBB dengan $p$ value sebesar 0,014. Persepsi dan pengetahuan individu serta keluarga tentang bahaya COVID-19 merupakan faktor penting yang mempengaruhi keputusan untuk melakukan perilaku yang dianjurkan, seperti social distancing dan perilaku hidup bersih dan sehat (PHBS). Persepsi terhadap bahaya COVID-19, paparan informasi kesehatan yang memadai dan mudah dipahami serta adanya dukungan sosial dapat memberikan pengaruh positif secara langsung terhadap perilaku tanggap COVID-19 yang mandiri (Sab'atmaja, dkk, 2020). 


\section{SIMPULAN DAN SARAN}

\section{Simpulan}

Pengetahuan sebagian besar responden termasuk kategori baik. Implementasi pencegahan COVID-19 sebagian besar responden termasuk kategori tinggi. Ada hubungan signifikan antara antara pengetahuan dan implementasi pencegahan COVID-19 pada praktik kebidanan komunitas. Hubungan antara variabel Pengetahuan dengan Implementasi Pencegahan COVID-19 adalah kuat dan bernilai positif bahwa jika pengetahuan semakin baik maka implementasi pencegahan COVID-19 akan semakin tinggi.

\section{Saran}

Bagi masyarakat diharapkan meningkatkan kepedulian terhadap pencegahan COVID-19 dengan mengikuti informasi terkini mengenai perkembangan kasus COVID-19 dan dapat mandiri dalam melakukan pencegahan COVID-19 melalui penerapan PHBS serta protokol kesehatan dengan lebih baik. Bagi tenaga kesehatan dan instansi kesehatan diharapkan melanjutkan pemantauan kedisiplinan warga masyarakat dalam melakukan protokol kesehatan pencegahan penularan COVID-19. Bagi peneliti selanjutnya diharapkan dapat mengkaji lebih dalam pengetahuan masyarakat tentang COVID-19 serta konsistensi atau kepatuhan implementasi pencegahan infeksi virus corona.

\section{DAFTAR PUSTAKA}

BNPB. 2020. Pedoman Perubahan Perilaku Penanganan COVID-19. https://covid19.go.id/p/protokol/pedoman-perubahan-perilakupenanganan-covid-19

Burhan, E, dkk. 2020. Pneumonia COVID-19 Diagnosis dan Penatalaksanaan di Indonesia. Jakarta: Perhimpunan Dokter Paru Indonesia.

Ganing, A., Salim, A., \& Muslimin, I. (2020). Studi Literatur: Pengetahuan sebagai Salah Satu Faktor Utama Pencegahan Penularan COVID-19. Jurnal Kesehatan Manarang, 6(Khusus), 55-60. https://www.jurnal.poltekkesmamuju.ac.id/index.php/m/article/download/ $\underline{340 / 119}$

Gannika, L, Erika ES. 2020. Tingkat Pengetahuan dan Perilaku Pencegahan Coronavirus Disease 2019 (COVID-19) Pada Masyarakat Sulawesi Utara. NERS: Jurnal Keperawatan, 16, (2), 83-89.

Ginting, MBR, dkk. 2020. Buku Tanya Jawab Seputar Virus Corona (COVID19). Jakarta: Kemenkes RI (September 2020)

Ginting, MBR, dkk. 2020. Strategi Komunikasi Perubahan Perilaku (KKP) Dalam Pencegahan COVID-19. Jakarta: Kemenkes RI.

Kemenkes RI. 2020. Pedoman Pemberdayaan Masyarakat Dalam Pencegahan COVID-19 Di RT/RW/Desa. Jakarta: Kemenkes RI.

Kemenkes RI. 2020. Tanya Jawab Seputar Virus Corona. Jakarta: Kementerian Kesehatan RI. (Mei 2020) https://promkes.kemkes.go.id/materi-tanyajawab-seputar-virus-corona 
Pasaribu, I, Intan E, Muhammad NAR, Winitra RA. 2020. Panduan Petugas Promosi Kesehatan Puskesmas Dalam Penanggulangan COVID-19. Jakarta: Kemenker RI.

Permenkes RI Nomor 8 Tahun 2019 tentang Pemberdayaan Masyarakat Bidang Kesehatan.

Pusdiklatnakes RI. 2014. Buku Ajar Kesehatan Ibu dan Anak. Jakarta: Kemenkes RI

Putra, AIYD, Made SAP, Made VWY, Gufran RDG, Ghaniy MG, Agnes MA, Evelyn A, I Putu GDWA, I Gusti AAS. 2020. Gambaran Karakteristik Pengetahuan, Sikap dan Perilaku Risiko Covid-19 Dalam Kerangka Desa Adat di Desa Gulingan, Mengwi, Bali. Jurnal Kesehatan Andalas, 9(3), 313-319.

http://jurnal.fk.unand.ac.id/index.php/jka/article/download/1402/1121

Rahayu, S, dkk. 2020. COVID-19: The Nightmare or Rainbow. Jakarta: Mata Aksara. https://thesiscommons.org/tvyuw/download?format=pdf

Sab'atmaja, S, Dina AS, Chandra R, dan Dwi AM. 2020. Panduan Kemitraan dalam Pencegahan COVID-19. Jakarta: Kementerian Kesehatan RI.

Sari, D. P., \& Sholihah'Atiqoh, N. 2020. Hubungan Antara Pengetahuan Masyarakat Dengan Kepatuhan Penggunaan Masker Sebagai Upaya Pencegahan Penyakit Covid-19 Di Ngronggah. INFOKES Journal, 10(1), 52-55.

Syakurah, R. A., \& Moudy, J. 2020. Pengetahuan terkait usaha pencegahan Coronavirus Disease (COVID-19) di Indonesia. HIGEIA (Journal of Public Health Research and Development), 4(3), 333-346.

WHO. 2020. Ikhtisar Kegiatan - 7. Coronavirus Disease 2019 (COVID-19). https://www.google.com/url?sa=t\&rct=j\&q=\&esrc=s\&source=web\&cd=\& cad=rja\&uact=8\&ved=2ahUKEwiy0ciw 4PuAhVUX30KHf7VDocQFjA MegQIDRAC\&url=https\%3A\%2F\%2Fwww.who.int\%2Fdocs\%2Fdefaultsource\%2Fsearo\%2Findonesia\%2Fcovid19\%2Fikthtisar-kegiatan-712nov2020.pdf\%3Fsfvrsn\%3D16e9c1fd_2\&usg=AOvVaw3qGxN_JefXp R-Gm2fxgNpg

Wiranti, W., Sriatmi, A., \& Kusumastuti, W. 2020. Determinan Kepatuhan Masyarakat Kota Depok terhadap Kebijakan Pembatasan Sosial Berskala Besar dalam Pencegahan Covid-19. Jurnal Kebijakan Kesehatan Indonesia: JKKI, 9(3), 117-124.

Yanti,NPE, I Made ADPN, Gede AW, Ni Putu DA, \& Ni Putu AD. 2020. Gambaran Pengetahuan Masyarakat Tentang COVID-19 dan Perilaku Masyarakat di Masa Pandemi COVID-19. Jurnal Keperawatan Jiwa , 8 (3), 485-490. https://jurnal.unimus.ac.id/index.php/JKJ/article/download/6173/pdf. 